\title{
Memory and Oral Testimony in Agatha Christie's Elephants Can Remember
}

Bendy Ann Cherian

Lecturer

Department of English

Morning Star Home Science College

Angamaly, Kerala, India

bendyanncherian@gmail.com

\begin{abstract}
Detection is a serious venture that depends heavily on oral testimonies and evidence. While partaking in the process of detection, the detective and the ones who testify put their capacity to think and memorise to test. Oral testimonies of people who witness or narrate the same event may vary due to the variations in the person- specific performance of the faculty of memory. The various functions of memory will also define and re- define a person's knowledge about another person or an event. This paper is an attempt to trace such patterns of memory and oral testimony that decides the course of the detection of an event that happened much earlier, as portrayed in Agatha Christie's Elephants Can Remember.
\end{abstract}

Keywords- Memory, Oral testimony, Crime, Detection.

Introduction

Agatha Christie's Elephants Can Remember, published in the year 1972, is a quest that her detective Hercule Poirot engages in to untangle a mystery. The mystery discussed in 
the book involves the tragic deaths of General Ravenscroft, his wife Lady Ravenscroft or Molly and Molly's sister Dolly. Mrs. Oliver, the godmother of the daughter of the Ravenscrofts, requests Poirot to solve the mystery as she was pestered to do so by Mrs. Burton-Cox, the in-law-to-be of her goddaughter, Celia Ravenscroft. The mystery is untangled organically through the twenty chapters. Chapters three to ten from book one, titled 'Elephants' and the following chapters form book two, titled "Long Shadows". "The mention of elephants is deliberate, elephants own excellent memory that remains undisturbed for years" (Finn). This paper is attempts to analyse the role of memory and oral testimony in the novel Elephants Can Remember.

Detection, Memory and Oral Testimony: An Inter- play of Facts and Fallacies

Ian M L Hunter, in his book Memory: Facts and Fallacies, suggests, "Memory, like the word 'life, refers not to static entities but to a vast number of interrelated activities or processes" (14). To understand anything about memory one should study these activities or processes. The four basic processes of memory are learning, remembering, forgetting and retaining. The sensory organs aid learning. This learning is made effective by habit or rather the repetitive exposure to that which has to be learned. To learn is to be aware as well. One remembers what one learns well. The failure to remember completely or partially is yet another activity of one's memory that is forgetting. Retaining involves recollection and recognition. Recollection is the act of recreating or reproducing some past activity or experience. Recollection is the process that helps in the progress of Elephants Can Remember because elephants are masters in recollection.

The reference to elephants, as mentioned earlier, is deliberate. In the novel, The 'Elephants' help Poirot in solving the mystery involved. Christie makes the first reference to elephants in the second chapter of the book titled "First Mention of Elephants". The reader is 
introduced to these 'elephants' as Christie brings forth their meeting either with Poirot or with Mrs. Oliver. Christie's 'elephants' are men and women who have commendable memory in comparison with other people. The reflections of the 'elephants' help Poirot in tracing "certain facts which have lingered in [their] memories" (113). These facts unfold the mystery towards the final pages of the book.

The 'elephants' are Superintendent Garroway-the officer who investigated the tragedy ten years ago, Honourable Julia Carstairs- an old friend of Mrs. Oliver, Mrs. Matcham- a former nursemaid to the Ravenscrofts, Mrs. Buckle- a former cleaner to the Ravenscrofts, Mrs. Rosentelle- the wig maker, Maddy- former governess of the Ravenscrofts, Zelie- former governess of the Ravenscrofts and Dr. Willoughby- a psychiatrist specialising in identical twins. Mr. Goby-a private investigator-and Mrs. Oliver help Poirot in gathering certain vital information that helps in ordering the 'facts' that Poirot arrives at. Poirot picks these facts after contesting them with all possible confusions that arise as a result "memories leading to theories" that the 'elephant' furnish (113). Sigmund Freud points out that "The formation of a concealing memory depends on the forgetting of other important impressions" (34).

The oral testimonies put forward by the 'elephants' are left incomplete as Christie intends to save the mystery until the end- the whodunit element- for Poirot to unravel it. There is a psychological explanation to the incompleteness of testimonies. We learn and remember things in the way we interpret those. As Hunter puts it, "We human beings universally and spontaneously try to understand to make sense of any situation which presents itself. And the way in which we do this is to relate the new situation to those situations which we have encountered in the past" (84). This is another reason for the mismatching testimonies on a single issue and thereby the confusion associated with the issue. Poirot says that "They [-the 'elephants'-] have made up the solution of something they 
knew about” (112). Rumours, gossips, and folk tales fuel this very confusion; “...both rumours and folk-tales merit mention in any book devoted to memory" (Hunter 103).

The 'elephants' share more or less the same memory regarding the tragic event- the deaths of Mr and Mrs Ravenscroft- but they do provide a distinctly different clue about the event in their narration that structures the solution to the mystery. The similar narration that they put forward is:

Sir Alistair Ravenscroft and Lady Ravenscroft. A very happy couple ...they'd been all over the world. They then bought this house [Overcliffe] ...then there were suddenly accounts of this case in the papers. Whether somebody else had killed them or whether they'd been assassinated or something, or whether they killed each other. ...It was a revolver that had been in the house for ages...

The narration varies with certain aspects that each 'elephant' focuses on or points out; it could also be something that invites Poirot's attention. When an 'elephant' discusses the 'possible reasons' for the visit of the Ravenscrofts to London, Poirot pays much attention to the 'fact' that they had been to London, in a hospital, during a certain period of their life.

Poirot, being a keen observer watches out for facts in the oral testimonies of the 'elephants'. Thus, he deduces certain inevitable clues like the dog of the Ravenscrofts and its strange behaviour for a few weeks before the tragic event, the four wigs that Lady Ravenscroft owned, the possible hatred between the identical twin sisters and the role of money in the mystery. The testimonies surface certain confusions as well; say the gossips concerning the extra marital affairs of Mr and Mrs Ravenscroft, Molly's cancer, Dolly's mental illness and sleepwalking, and the criminal background of the gardener at Overcliffe. Considerable amount of effort is put in by Poirot to defy these gossips as the causes of the tragedy. He says, "So there have been memories leading to theories- theories of infidelity, of 
illness, of suicide pacts, of jealousy, all these things have been suggested to you. Further search could be made as to points if they seem in any way probable" (113).

The 'facts' in the oral testimonies, born out of the memory of the 'elephants', provide immense help in solving the mystery. It directs the investigation that Poirot undertakes. By putting together the instances of the dog biting its mistress Molly, her ordering new wigs a few weeks before the tragedy and the knowledge of Mr. Ravenscroft's initial affair with Dolly, Poirot identifies a possibility of personality exchange between Dolly and Molly. Poirot arrives at certain assumptions; say the dog bit not its mistress Molly but Dolly who was in disguise of Molly. Dr. Willoughby's research on identical twins alerts Poirot about the hatred that arises between identical twins after a certain point in life. This along with Mr. Ravenscroft's rejection of Dolly's love and Dolly's mental illness provided enough reason for Poirot to suspect a murder. Poirot on visiting the grave of the Ravenscrofts and Dolly was taken aback by the realisation that they who shared the same grave had a share of theirs in the tragedy too. His thoughts then shifted to the external help involved in the tragedy, the 'French lady', who according Mrs. Rosentelle collected the wigs on behalf of Molly. His thoughts attained salvation on meeting Zelie-the 'French lady'- who used to be a governess to the Ravenscrofts.

In the nineteenth chapter of Elephants Can Remember, titled "Maddy and Zelie", Poirot unmasks the truth behind the tragic mystery after an informal interrogation with Zelie, the perfect elephant. Zelie's testimony negates the voids in the mystery. Her memory and oral testimony brings a very appealing end to Poirot's quest and the book as well. She confesses the story involving the "same wig- different woman" (206). She narrates the tragic events to Poirot in front of the other major characters. Poirot asserts that “...we have here not only a murder and also a suicide, but we have as well what I shall call an execution, and we have a tragedy also" (204). The reader eventually learns from Zelie that it was Molly who died 
initially, and not Dolly. Dolly pushes her sister down the cliff. By the time Mr. Ravensrcoft approaches Molly to offer help she dies asking him to protect her sister. Dolly then moves around in the guise of Molly. Mr. Ravenscroft realises eventually that the only way to keep his promise to his wife is to kill Dolly. Death alone has the potential to offer ultimate protection, and hence Mr.Ravenscroft shoots Dolly and himself. He had discussed his plans priorly with Zelie, though not clearly. It was after the tragedy that his words made complete sense to her.

\section{Conclusion}

A mystery that was left unsolved for over ten years was thus solved in a matter of weeks by totally depending on the memory and oral testimony of the 'elephants'. Memory and oral testimony are thus the most integral elements of this detective novel. The book later inspired a number of movies and other books in making effective use of memory and oral testimony. Zelie makes a vain attempt to repress her memories. Repression is a deliberate or forceful attempt to forget .The book ends with a remark by Mrs Oliver "Elephants can remember... but we are human beings and mercifully human beings can forget" (218). Forgetting, as Hunter suggests, is yet another activity of memory. 


\section{Works Cited}

Christie, Agatha. Elephants Can Remember. Harper Collins Publishers, 1972.

Finn, Mike. “Elephants Can Remember by Agatha Chrsitie”. Wordpress, 13 Jan. 2017, www.mikefinnsfictio.wordperess.com/2017/01/13/ elephants-can-remember-byagatha-christie

Freud, Sigmund. Psychopathology of Everyday Life. T. Fisher Unwin, 1914.

Hunter, Ian M L. Memories: Facts and Fallacies. Pelican Book Publishing, 1957. 